\title{
Perbaikan Teknologi Pengemasan Pada Usaha Mikro Kecil Menengah Kerupuk Lipat Di Desa Pondok Meja Muaro Jambi
}

\author{
Surhaini, Rahayu Suseno, Ulyarti, Addion Nizori dan Mursalin \\ Dosen Fakultas Teknologi Pertanian Universitas Jambi \\ Email: rahayususeno@gmail.com
}

\begin{abstract}
Abstrak: Pengabdian pada masyarakat (PPM) Jurusan Teknologi Hasil Pertanian Fakultas Teknologi Pertanian, Universitas Jambi dengan salah satu usaha mikro kecil menengah (UMKM) kerupuk lipat di Desa Pondok Meja Muara Jambi telah melakukan pengabdian dengan tujuan mengatasi permasalahan mitra, yaitu teknologi pengemasan yang rendah serta umur simpan yang pendek. Tim pengabdian bertindak sebagai fasilitator dan instruktur dalam pelatihan/pendampingan antara lain perbaikan penggunaan teknologi pengemasan dan peningkatan umur simpan. Selama ini UMKM kerupuk lipat Pondok Meja hanya melakukan pengemasan dengan menggunakan karet/tali plastik pada plastik kemasan sehingga memiliki umur simpan yang pendek dan pengerjaan pengemasan yang lama yang dapat memperlambat waktu produksi. Hasil pelatihan diketahui dapat meningkatkan pemahaman mitra dalam meningkatkan penggunaan teknologi pengemasan yang baik sehingga produk kerupuk lipat yang diproduksi menjadi lebih tahan lama dan mengurangi waktu produksi yang sebelumnya membutuhkan waktu lebih lama.
\end{abstract}

Kata Kunci : Kerupuk Lipat, Kemasan, Umur Simpan

\section{PENDAHULUAN}

UMKM (Usaha Mikro Kecil Menengah) memegang peranan yang sangat besar dalam memajukan perekonomian Indonesia.Selain sebagai salah satua lternatif lapangan kerja baru, UMKM juga berperan dalam mendorong laju pertumbuhan ekonomi pasca krisis moneter tahun 1997 di saat perusahaan-perusahaan besar mengalami kesulitan dalam mengembangkan usahanya. Saat ini, UMKM telah berkontribusi besar pada pendapatan daerah maupun pendapatan Negara Indonesia (Tambunan, 2012).

UMKM merupakan suatu bentuk usaha kecil masyarakat yang pendiriannya berdasarkan inisiatif seseorang. Sebagian besar masyarakat beranggapan bahwa UMKM hanya menguntungka pihak-pihak tertentu saja. Padahal sebenarnya UMKM sangat berperan dalam mengurangi tingkat pengangguran yang ada di Indonesia. UMKM dapat menyerap banyak tenagakerja Indonesia yang masih mengganggur. Selain itu UMKM telah berkontribusi besar pada pendapatan daerah maupun pendapatan negara Indonesia.

UMKM mendorong pengembangan inovasi dan teknologi. Usaha Mikro Pembuatan kerupuk lipat beralamat Di JlJalan Tribrata RT.12, Dusun Karya Maju Desa Pondok Meja Kecamatan Mestong, Muara Jambi. Usaha ini telah berdiri semenjak tahun 2009. Pemilik usaha ini bernama Bapak Nunu Nugraha yang meneruskan usaha secara kekeluargaan.

Barang yang didagangkan berupa kerupuk lipat dengan bahan seperti: tepung tapioka, tepung terigu, bumbu (garam, merica, bawang merah, dan bawang putih), air, dan minyak goreng. Peralatan yang di gunakan adalah: kuali, serok, alat penekan, ebeg, loyang, plastik, kompor, dan tali rafia. dengan total 1 kali produksi $30-50 \mathrm{~kg}$ dengan kerupuk yang dihasilkan sebanyak 1000 bungkus. dengan harga 1 bungkus kerupuk sebesar Rp 3.000,00 Keuntungan yang di peroleh dalam 1 kali pemasaran sebesar Rp 2.000.000,00. 


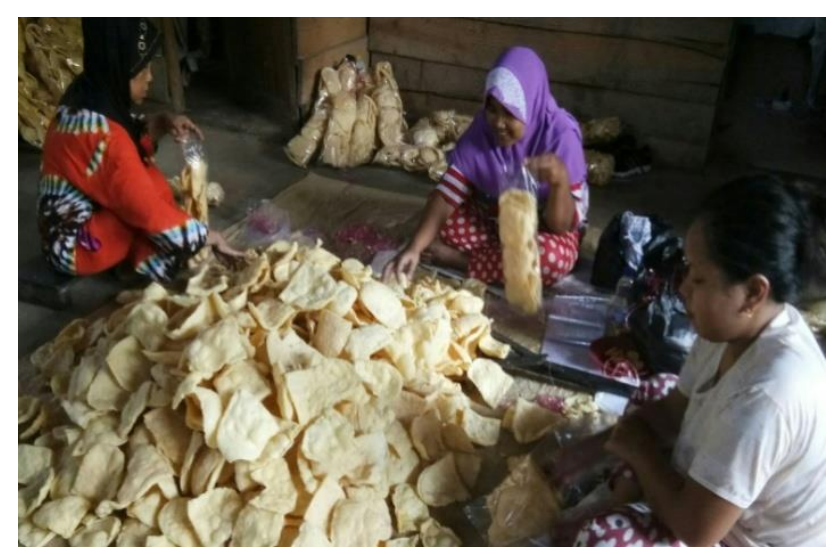

Gambar 1. Proses pengemasan kerupuk lipat

Pengemasan merupakan salah satu cara menghambat uap air lingkungan terserap oleh produk pangan kering. Kemasan juga dapat mencegah atau mengurangi kerusakan, melindungi bahan yang ada di dalamnya dari pencemaran serta gangguan fisik seperti gesekan, benturan dan getaran (Triyanto, dkk., 2013). Oleh karenanya pengemasan dapat memperpanjang umur simpan dan mempertahankan kualitas bahan lebih lama dalam hal ini umur simpan kerupuk lipat.

Permasalahan yang dihadapi oleh usaha mikro kecil dan menengah (UMKM) kerupuk lipat adalah umur simpan produk kerupuk lipat yang tidak bertahan lama karena mudah melempem yang disebabkan oleh pengemasan yang tidak baik. Waktu mengemas produk juga menjadi kendala karena pengemasan produk menggunakan karet dan tali maka membutuhkan waktu pengerjaan yang cukup lama sehingga untuk memenuhi permintaan pasar yang cukup tinggi menjadi lebih lama. Produk kerupuk lipat ini merupakan produk kering yang seharusnya memiliki umur simpan yang lama. Melalui proses pengemasan yang lebih baik diharapkan dapat memperpanjang umur simpan produk kerupuk.

\section{METODE PELAKSANAAN}

Kegiatan pengabdian pada masyarakat (PPM) dilaksanakan pada bulan MaretSeptember 2018 di UMKM kerupuk lipat Desa Pondok Meja Kecamatan Mestong Kabupaten Muara Jambi Provinsi Jambi. Alat dan bahan yang digunakan dalam kegiatan ini, antara lain: kerupuk lipat siapkemas, plastik pengemas dan alat pengemas berupa hand sealer.Kegiatan Iptek bagi Masyarakat (IbM) dengan mitra UMKM kerupuk lipat Desa Pondok Meja dilakukan berdasarkan hasil identifikasi situasi dan permasalahan. Berdasarkan kesepakatanantara tim PPM Jurusan Teknologi Hasil Pertanian Fakultas Teknologi Pertanian, Universitas Jambi dan mitra UMKM kerupuk lipat Desa Pondok Meja. Dalam upaya penyelesaian masalah, dilakukan beberapa pendekatan yaitu proses pemahaman tentang peningkatan mutu produk kerupuk lipat yang telah dikemas melalui proses pengemasan yang baik serta peningkatan kualitas dan umur simpan produk kerupuk lipat.

\section{HASIL DAN KETERCAPAIAN SASARAN}

Kegiatan pengabdian pada masyarakat ini dilaksanakan pada bulan Juli, Agustus dan September 2018 di Usaha Mikro Kecil dan Menengah (UMKM) kerupuk lipat. Adapun peserta yang terlibat adalah pemilik dan penanggung jawab UMKM dan karyawan yang ada pada UMKM tersebut. Adapun tahapan awal yang dilaksanakan adalah melakukan survey dan 
kunjungan ke lokasi tempat akan dilakukan pengabdian. Survey dilakukan pada bulan Juli 2018, selain survey awal juga dilakukan permintaan persetujuan UMKM untuk menjadi mitra pada kegiatan pengabdian ini.

Saat penandatanganan kesediaan untuk bekerja sama, dipaparkan pula kepada pemilik UMKM dan sebagian anggotanya tentang seluruh rencana kerja program dan nilai penting program terhadap pemecahan masalah yang dihadapi oleh UMKM mitra sasaran. Selain perjanjian kerja sama UMKM diminta untuk menghimpun seluruh karyawan saat akan dilakukan penyuluhan dan bimbingan teknis, serta menyiapkan tempat untuk pertemuan, penyuluhan dan bimbingan teknis selama pelaksanaan kegiatan.

Selama kegiatan berlangsung, para karyawan dan penanggung jawab di UMKM juga ikut membantu dalam menyiapkan bahan dan peralatan untuk pelatihan dan pembimbingan teknis. Selain itu para karyawan yang menjadi peserta penyuluhan turut bekerja sama dalam mensukseskan program pelatihan dan pembimbingan sehingga karyawan dapat benar-benar menerima iptek yang ditransferkan kepada mereka.

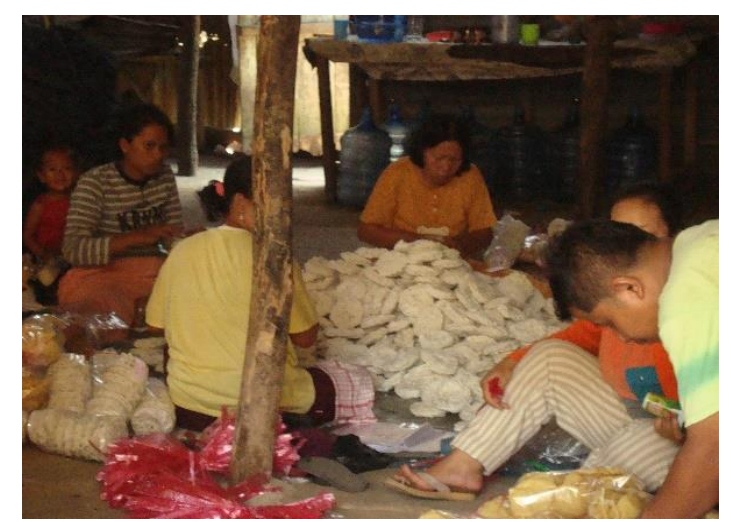

Gambar 2 Proses Penyuluhan dan pembimbingan teknik pengemasan pada UMKM kerupuk lipat saat proses pengemasan

Kegiatan penyuluhan dilakukan oleh ketua pelaksana yang dibantu dengan anggota dan mahasiswa dalam memberikan pelatihan dan bimbingan teknis mengenai teknik memperpanjang umur simpan produk dan pengemasan produk. Pada saat pelatihan disampaikan bahwa dengan menggunakan teknologi dalam mengemas produk maka dapat meningkatkan jumlah produksi pada UMKM. Proses pembimbingan berlangsung dengan cara mengumpulkan pekerja yang sedang tidak berproduksi dan dilakukan juga dengan pembimbingan langsung pada saat pekerja sedang melakukan pengemasan. Hal ini dilakukan agar proses produksi dapat terus berjalan sehingga proses penyuluhan tidak mengganggu produksi.

Setelah dilakukan penyuluhan penggunaan alat pengemas berupa sealer, para pekerja pada mulanya kesulitan untuk menggunakan alat tersebut namun lama kelamaan semakin mahir sehingga kerupuk lipat yang dijual kini sudah tidak diikat menggunakan tali plastik lagi. Produk kerupuk lipat yang dipasarkan kini menjadi tidak mudah melempem dan menjadi lebih tahan lama. 


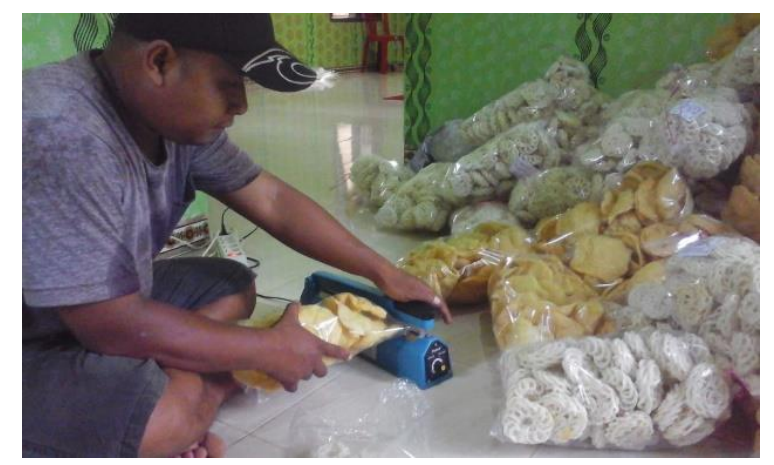

Gambar 3 Proses pengemasan kerupuk menggunakan sealer

\section{KESIMPULAN}

Simpulkan hasil pengabdian kepada masyarakat baik dalam bentuk keberhasilan maupun hambatan yang ditemukan dalam kegiatan. Hambatan yang tertera pada bagian ini menjadi peluang bagi penulis untuk menyampaikan saran untuk keberlanjutan dan perbaikan dimasa datang.

\section{DAFTAR PUSTAKA}

Tambunan, Tulus. (2012). Perekonomian Indonesia. Bogor: Gahlia Indonesia

Triyanto E., B.W.H.E. Prasetiyono, dan S. Mukodiningsih. (2013). Pengaruh Bahan Pengemas dan Lama Simpan terhadap Kualitas Fisik dan Kimia Wafer Pakan komplit Berbasis limbah Agroindustri. Animal Agriculture Journal, 2 (1), 400- 409. 